\title{
PENGALAMAN MAHASISWA PROFESI NERS FAKULTAS KEPERAWATAN UNIVERSITAS SUMATERA UTARA DALAM MENERAPKAN PERILAKU CARING PADA PASIEN DI RUMAH SAKIT PENDIDIKAN KOTA MEDAN
}

\author{
Professional Students Experiences Ners Faculty Of Nursing University Of North Sumatera In Applying \\ Caring Behavior In Patients In Hospital Hospital Of Medan City
}

\author{
Afina Muharani Syaftriani ${ }^{1}$, Setiawan ${ }^{2}$ \\ ${ }^{1}$ Akademi Keperawatan Kesdam I/Bukit Barisan Medan \\ Email: afinalubis@gmail.com \\ ${ }^{2}$ Departemen Keperawatan Dasar dan Keperawatan Medikal Bedah Fakultas Keperawatan USU \\ Email: setiawan@usu.ac.id
}

\begin{abstract}
Abstrak
Perilaku caring adalah suatu tindakan yang didasari oleh kepedulian, kasih sayang, keterampilan, empati, tanggung jawab, sensitif dan dukungan. Pemberian pelayanan keperawatan yang didasari oleh perilaku caring mampu meningkatkan kualitas pelayanan kesehatan. Perilaku caring tidak hanya dilakukan oleh perawat tetapi juga dilakukan oleh mahasiswa yang sedang menjalankan tahap pendidikan profesi ners di rumah sakit. Penelitian ini bertujuan untuk mengeksplorasi pengalaman mahasiswa profesi ners Fakultas Keperawatan Universitas Sumatera Utara dalam menerapkan perilaku caring pada pasien di Rumah Sakit Pendidikan Kota Medan. Penelitian ini menggunakan desain fenomenologi. Teknik pengambilan sampel yang digunakan adalah purposive sampling dengan jumlah partisipan sebanyak sepuluh orang partisipan. Sebelum pengambilan data, peneliti mengajukan ethical clearance yang diperoleh melalui Komisi Etik Penelitian Kesehatan Fakultas Keperawatan Universitas Sumatera Utara. Penelitian ini dilaksanakan di Fakultas Keperawatan Universitas Sumatera Utara pada bulan Februari 2015 sampai dengan bulan April 2015. Data yang diperoleh dianalisis menggunakan metode Collaizi. Penelitian ini menemukan ada 4 tema terkait dengan pengalaman mahasiswa profesi ners Fakultas Keperawatan Universitas Sumatera Utara dalam menerapkan perilaku caring pada pasien di Rumah Sakit Pendidikan Kota Medan, yaitu (1) memperlihatkan rasa peduli yang tinggi dalam menerapkan caring, (2) menjalin komunikasi yang menciptakan trust dengan pasien, (3) melakukan tindakan keperawatan secara holistik kepada pasien, (4) menunjukkan sikap menghormati pasien. Selain pengalaman tersebut, penelitian ini juga mengungkapkan dampak perilaku caring (5 dampak) dan hambatan yang dialami mahasiswa profesi ners dalam menerapkan perilaku caring (3 hambatan). Mengingat pentingnya penerapan perilaku caring tersebut, maka direkomendasikan kepada mahasiswa pendidikan tahap profesi ners untuk terus meningkatkan perilaku caring kepada pasien. Selanjutnya, bagi institusi pendidikan keperawatan ataupun rumah sakit dapat membuat standar perilaku caring sehingga dapat meningkatkan kualitas pelayanan kepada pasien.
\end{abstract}

Kata Kunci : mahasiswa profesi ners, perilaku caring, rumah sakit pendidikan

\begin{abstract}
Caring behavior is an act based on caring, affection, skill, empathy, responsibility, sensitivity and support. Provision of nursing services based on caring behavior can improve the quality of health services. Caring behavior is not only performed by nurses but also performed by students who are running the professional education phase ners in the hospital. This study aims to explore the experiences of professional students ners Faculty of Nursing University of North Sumatra in applying caring behavior in patients at Medan City Education Hospital. This research uses phenomenology design. The sampling technique used was purposive sampling with a total of ten participants. Prior to the data retrieval, the researcher proposed the ethical clearance obtained through the Research Ethics Commission of the Faculty of Nursing University of North Sumatra. This research was conducted at Faculty of Nursing University of Sumatera Utara in February 2015 until April 2015. The data obtained were analyzed by Collaizi method. This study found there are 4 themes related to the experience of nursing students of Faculty of Nursing University of North Sumatera in applying caring behavior to patients in Medan Education Hospital, that is (1) showing high caring in caring, (2) trust with the patient, (3) performing a holistic nursing action to the patient, (4) showing respect for the patient. In addition to these experiences, this study also reveals the impact of caring behavior (5 impacts) and barriers experienced by professional students in applying caring behavior (3 barriers). Given the importance of the application of caring behavior, it is recommended to the students of professional education stage ners to
\end{abstract}


continue to improve caring behavior to patients. Furthermore, for nursing education institutions or hospitals can create caring behavior standards so as to improve the quality of service to patients.

Keywords: professional student ners, caring behavior, hospital education

\section{PENDAHULUAN}

Caring secara umum dapat diartikan sebagai suatu kemampuan untuk berdedikasi bagi orang lain, pengawasan dengan waspada, menunjukkan perhatian, perasaan empati pada orang lain dan perasaan cinta atau menyayangi yang merupakan kehendak keperawatan ${ }^{[1]}$. Perilaku caring sangat penting bagi perawat yang bertugas di rumah sakit. Perawat yang caring, cerdas dan terampil akan memberikan keamanan, kenyamanan dan kepuasan pada klien dan keluarga serta membawa dampak positif terhadap citra rumah sakit, citra profesi perawat di mata klien, keluarga bahkan masyarakat pada umumnya. Perilaku caring tidak hanya dilakukan oleh perawat tetapi juga dilakukan oleh mahasiswa tahap pendidikan profesi ners. Aplikasi perilaku caring pada mahasiswa dalam tahap pendidikan profesi ners sangat penting diterapkan karena ini adalah tempat pertama bagi mahasiswa untuk belajar tentang nilai-nilai dan esensi dari profesi mereka.

\section{TINJAUAN PUSTAKA}

Perilaku caring menurut Watson (1979) adalah proses yang dilakukan perawat meliputi pengetahuan, tindakan dan dideskripsikan sebagai sepuluh faktor karatif yang digunakan dalam praktik keperawatan di beberapa setting klinik yang berbeda.

Watson (1979) menambahkan bahwa caring yang dilakukan dengan efektif dapat mendorong kesehatan dan pertumbuhan individu ${ }^{[4]}$. Selain itu, perilaku caring perawat memberi pengaruh dalam pelayanan yang berkualitas pada pasien. Perilaku caring perawat juga memberikan kontribusi besar terhadap kualitas pengalaman pasien selama dilakukan perawatan.

Mahasiswa keperawatan akan memulai program pendidikan profesi keperawatan setelah lulus dari program pendidikan akademik. Pada tahap pendidikan profesi mahasiswa akan mengaplikasikan seluruh pengetahuan dan teori yang telah didapat selama pendidikan akademik ke dalam masalah klinik yang nyata.

Perilaku caring juga dilakukan oleh mahasiswa yang sedang melaksanakan program pendidikan profesi ners. Salah satu penerapan perilaku caring mereka adalah kehadiran ${ }^{[8]}$. Kehadiran disini meliputi keberadaan mahasiswa profesi ners dalam memberikan waktunya untuk mendengarkan secara aktif dan sensitif terhadap pasien yang mereka rawat. Perilaku caring lainnya meliputi mendukung dan memberikan perhatian ke pasien tanpa mengharapkan imbalan apa pun, menunjukkan rasa hormat terhadap pasien, berbicara dengan pasien dan bersikap jujur dengan pasien.

\section{METODE}

Desain penelitian yang digunakan dalam penelitian ini adalah fenomenologi. Partisipan pada penelitian ini sebanyak sepuluh orang mahasiswa Fakultas Keperawatan Universitas Sumatera Utara semester 2 tahap profesi yang sedang menjalankan program pendidikan profesi ners dan berasal dari program reguler (mahasiswa jalur A).

Pengumpulan data dilakukan setelah mendapat izin dari Dekan Fakultas Keperawatan Universitas Sumatera Utara dan memperoleh ethical clearance dari Komisi Etik Penelitian Kesehatan Fakultas Keperawatan Universitas Sumatera Utara. Selanjutnya peneliti melakukan pilot study. Setelah pilot study dilakukan, peneliti melakukan wawancara mendalam atau in-dept interview. Peneliti menggunakan alat perekam untuk merekam wawancara. Langkah selanjutnya adalah peneliti membuat transkrip hasil wawancara setiap kali selesai wawancara. Data yang diperoleh dianalisis dengan menggunakan metode Collaizi.

\section{HASIL}

Penelitian ini menemukan ada 4 tema terkait dengan pengalaman mahasiswa profesi ners Fakultas Keperawatan Universitas Sumatera Utara dalam menerapkan perilaku caring pada pasien di Rumah Sakit Pendidikan Kota Medan, yaitu (1) memperlihatkan rasa peduli yang tinggi dalam menerapkan caring, (2) menjalin komunikasi yang menciptakan trust dengan pasien, (3) melakukan tindakan keperawatan 
secara holistik kepada pasien, (4) menunjukkan sikap menghormati pasien.

\subsection{Memperlihatkan rasa peduli yang tinggi}

Partisipan dalam penelitian ini menyatakan bahwa salah satu bentuk mereka memperlihatkan rasa peduli yang tinggi dalam menerapkan caring adalah dengan peduli pada pasien. Peduli pada pasien tersebut dimaknai seperti siap sedia membantu memenuhi kebutuhan pasien. Hal ini sesuai dengan pernyataan dibawah ini:

"Caring itu adalah suatu sikap seseorang yang peduli, dan ramah kepada seseorang, ketika pasien memerlukan bantuan kita, kita siap sedia memfasilitasi kebutuhannya"

(Partisipan 4)

Partisipan dalam penelitian ini juga memperlihatkan rasa peduli yang tinggi kepada pasien dicontohkan dengan perhatian kepada pasien. Perhatian yang diberikan partisipan seperti bertanya pada pasien terkait kondisinya. Hal ini sesuai dengan pernyataan berikut:

"Perhatian juga bisa dicontohkan kayak kita tanya keadaan pasiennya "Gimana hari ini?" "Semalam gimana tidurnya? Enak? Ada gangguan?" Misalnya kalau ada gangguan, "Berapa jam tidurnya? Berapa kali terbangun? Apa yang membuat tidurnya ga nyenyak?"

(Partisipan 4)

\subsection{Menjalin Komunikasi yang Menciptakan} Trust dengan Pasien

Beberapa partisipan dalam penelitian ini mengatakan bahwa menjalin komunikasi yang menciptakan trust dengan pasien dapat dilakukan dengan komunikasi terapeutik. Komunikasi terapeutik dengan pasien dicontohkan dengan melakukan komunikasi yang baik dengan pasien. Hal ini sesuai dengan pernyataan berikut:

"Apapun yang kita lakukan baik itu untuk pasien, baik itu untuk prosedur rumah sakit, kita melakukannya dengan komunikasi yang betul-betul gimana ya, komunikasinya itu betul-betul baik kita sampaikan, harus tepat, dan masuk sama pasien”

(Partisipan 8)

Mahasiswa profesi ners dalam menerapkan perilaku caring pertama kali pada pasien berusaha untuk menciptakan trust pada pasien. Menciptakan trust pada pasien dapat dilakukan dengan melakukan komunikasi. Bentuk komunikasi yang dicontohkan partisipan pada penelitian ini seperti melakukan komunikasi saat pertama kali dengan pasien, memperkenalkan diri kepada pasien dan sebelum melakukan tindakan kepada pasien. Hal diatas sesuai dengan pernyataan partisipan dibawah ini:

"Bina trust kami memperkenalkan terlebih dahulu diri kami. Lalu kami menjelaskan apa yang kami lakukan, dinas disini berapa lama, kami jelaskan"

(Partisipan 8)

Partisipan yang lain juga menjelaskan bahwa penerapan perilaku caring yang mereka lakukan salah satunya adalah dengan memberikan penkes kepada pasien dan keluarga. Hal ini sesuai dengan pernyataan partisipan berikut:

"Melakukan caring ini pun kadangkadang kita bisa langsung berikan penkes juga sama keluarga pasien, contoh penyuluhan, "Ibu, ini kita ajarin penyuluhan tentang mencuci tangan yang benar"

(Partisipan 4)

4.3. Melakukan Tindakan Keperawatan secara Holistik kepada Pasien

Beberapa partisipan mengatakan bahwa pengalaman mereka dalam menerapkan perilaku caring salah satunya adalah dengan melakukan tindakan keperawatan secara holistik kepada pasien. Melakukan tindakan keperawatan secara holistik kepada pasien dicontohkan partisipan memberikan pelayanan yang menyeluruh kepada pasien, sesuai dengan pernyataan dibawah ini:

"terus kan kita harus perhatikan secara menyeluruh juga kebutuhan pasiennya maupun perilaku caring yang kita lakukan"

(Partisipan 9) 
Partisipan pada penelitian ini juga menjelaskan bahwa melakukan tindakan secara holistik tidak hanya stand by disamping pasien tetapi juga menerapkan pengetahuan dan tindakan keperawatan yang telah mereka dapatkan sebelumnya. Hal ini sesuai dengan pernyataan partisipan dibawah ini:

"Caring itu juga tidak hanya stand by disamping pasien sih tapi ketika kita punya knowledge yang baik, kita punya afektif yang baik, kita mengerti kebutuhan mereka, kita terapkan secara profesional"

(Partisipan 10)

Partisipan dalam penelitian ini menerapkan perilaku caring juga dengan cara memberikan intervensi keperawatan kepada pasien secara tepat. Beberapa intervensi keperawatan yang mereka berikan adalah dengan mengobservasi keadaan pasien. Hal ini sesuai dengan pernyataan dibawah:

"Sekali setengah jam observasi pasiennya apakah pasiennya demam atau nyeri, selalu itu. Per setengah jam observasi pasien, keadaannya kayak mana. Kan kadang-kadang bisa sekarang nyeri, nanti dua jam kemudian misalnya ga nyeri lagi yang lain lagi keluhannya"

(Partisipan 4)

\subsection{Menunjukkan Sikap Menghormati Pasien}

Partisipan dalam penelitian ini menjelaskan bahwa salah satu sikap caring yang sudah mereka terapkan kepada pasien yaitu dengan menunjukkan sikap menghormati pasien. Contoh sikap menghormati pasien yang sudah partisipan terapkan adalah menghargai pasien. Menghargai pasien dicontohkan juga oleh partisipan dengan tetap menyapa pasien meskipun pasien dalam kondisi tidak sadar, sesuai dengan pernyataan partisipan berikut:

"Kakak juga pernah dinas di ICU, banyak pasien ga sadar, bahkan pasienpasien penurunan kesadaran juga. Perilaku caringnya tetap sih, perkenalkan diri sambil menyentuh tubuhnya sih, menyapa dia sih "Selamat Pagi Bapak ini", kakak selalu sebutkan sih nama pasiennya, "Selamat Pagi Ibu ini", "Bapak Ini"

(Partisipan 10)

Selain pernyataan diatas, partisipan juga mengatakan bahwa untuk menghargai pasien mereka berusaha untuk menganggap pasien seperti keluarganya sendiri ketika merawatnya. Hal ini sesuai dengan pernyataan di bawah ini:

"Satu yang penting, anggaplah pasien itu memang benar-benar seperti keluarga kita. Jadi kalau kita udah anggap itu keluarga kita, udah capek kalipun ini, udah ngantuk kali, udah gimana kan "Sus tolonglah, cairan infusnya habis", pasti kalau kita liat kita langsung "Ih kayak mana ya kalau misalnya ini keluargaku ya, kalau ku kerjakan begini gimana ya?", pastilah kita buat caring, maksudnya kita perlakukanlah pasien itu seperti keluarga kita, pasti caring itunya sendiri pasti akan muncul" (Partisipan 3)

Sebagai seorang perawat nantinya, mahasiswa profesi ners seharusnya terbiasa untuk menghargai pasien. Menghargai pasien diterapkan partisipan pada penelitian ini adalah dengan selalu mendahulukan kepentingan pasien daripada kepentingan pribadi partisipan itu sendiri. Hal ini sesuai dengan pernyataan berikut:

\begin{abstract}
"Ketika mereka membutuhkan bantuan atau mereka mengeluh suatu hal..nah kita harus siap sedia walaupun kita lagi sibuk, walaupun kita lagi gak mood, kita harus siap sedia membantu mereka"
\end{abstract}

(Partisipan 1)

Partisipan dalam penelitian ini menjelaskan sikap caring yang diterapkan kepada pasien salah satunya adalah dengan ramah pada pasien. Ramah yang ditunjukkan partisipan dicontohkan dengan menyapa pasien, sesuai dengan pernyataan partisipan dibawah ini:

"Aku juga sering misalnya kalau setiap.. kan biasanya kami di bagi tugas kan setiap ruangan, biasanya kakak selalu menyapa sih per bed-bed gitu kan"

(Partisipan 10) 
Partisipan dalam penelitian ini juga membiasakan diri untuk tersenyum ketika melihat pasien. Hal ini sesuai dengan pernyataan berikut:

"Dengan senyuman dek. Misalkan kakak juga observasi sih perawat-perawat yang lain seperti apa ya merawat pasien dan akan sangat berbeda ketika kita menyapa mereka dengan senyuman Yang kakak terapkan sih senyuman, ketika melihat pasien selalu senyum"

(Partisipan 10)

Selain tersenyum kepada pasien, partisipan pada penelitian ini juga membiasakan diri untuk menyentuh pasien saat berkomunikasi dengan pasien. Hal tersebut sejalan dengan pernyataan partisipan di bawah ini:

"Terus kakak sering sentuh sih, sering sentuh tubuhnya, gitu kan. Karna kakak juga merasakan kalau kita sedang kesakitan kita butuh dukungan orang lain dan itu bisa didukung dengan sentuhan, gitu. Kakak sering sih melakukan itu, pegang tangannya"

(Partisipan 10)

Selain pengalaman tersebut, penelitian ini juga mengungkapkan dampak perilaku caring dan hambatan yang dialami mahasiswa profesi ners dalam menerapkan perilaku caring.

\subsection{Dampak Perilaku Caring}

Berdasarkan hasil analisa data didapat 5 dampak perilaku caring. Lima dampak perilaku caring tersebut adalah mahasiswa profesi ners mengalami kepuasan batin, mahasiswa profesi ners merasa senang, pasien merasa nyaman, pasien sembuh, pengetahuan pasien bertambah.

Perilaku caring yang dilakukan mahasiswa profesi ners memiliki banyak dampak kepada mereka. Dampak perilaku caring yang dirasakan partisipan pada penelitian ini antara lain mahasiswa profesi ners mengalami kepuasan batin. Kepuasan batin disini dimaksudkan partisipan dengan partisipan merasa puas sudah memberikan pelayanan yang baik kepada pasien. Hal ini sesuai dengan pernyataan berikut:

"Efek dari caring itu sendiri yang pertama itu kita merasa puas dengan apa yang kita lakukan. Jadi ketika pasien merasa nyaman dengan tindakan kita kan ada kepuasan tersendiri bagi kita. Oh ini memang perawat ini memang bagus untuk kita"

\section{(Partisipan 1)}

Partisipan dalam penelitian ini juga merasakan kepuasan batin setelah mengaplikasikan perilaku caring karena mereka dapat merubah persepsi keluarga tentang perawat. Hal ini sesuai dengan pernyataan partisipan berikut:

"Kemudian kalau kita caring sama pasien, orang itu pun respon ke kita juga baik, dan juga bisa kita merubah image negatif dari masyarakat yang bilang kalau perawat itu pembantu dokter, padahal kita itu bukan pembantu dokter kita itu mitra"

(Partisipan 4)

Perilaku caring yang dilakukan mahasiswa profesi ners juga berdampak pada pasien. Hasil analisa data pada penelitian ini didapatkan salah satu dampak yang dirasakan pasien setelah diterapkannya perilaku caring adalah pasien merasa nyaman. Pasien merasa nyaman dengan mahasiswa profesi ners dicontohkan partisipan dengan pasien hanya mau dirawat dengan mahasiswa profesi ners. Sesuai dengan pernyataan berikut:

"Ada sih pasien merasa nyaman, ada juga sampai pasien ga mau pulang, disini perawatnya baik-baik, ada yang kayak gitu juga jadinya"

(Partisipan 7)

Dengan diterapkannya perilaku caring kepada pasien, pasien menjadi percaya dengan mahasiswa profesi ners. Maksudnya disini adalah pasien hanya percaya pada mahasiswa profesi ners yang akan melakukan tindakan keperawatannya. Hal ini sesuai dengan pernyataan dibawah ini:

"Percaya disini misalkan dalam melakukan tindakan keperawatan mereka lebih percaya kita yang mengerjakan. Dan kita jadi tempat bertanya mereka. Dari situ kan peran kita sebagai perawat juga sebagai edukator kan, jadi itu sejalan semuanya bisa dikerjakan"

(Partisipan 10) 
Beberapa partisipan pada penelitian ini mengatakan dengan diterapkan perilaku caring maka dapat mempercepat proses penyembuhan pasien. Sesuai dengan pernyataan berikut:

"Manfaat yang lain ya karena kita caring misalnya pasiennya resiko infeksi, karna kita sering observasi dan penatalaksaan infeksi dia lebih ini..lebih cepat lah proses penyembuhannya dari pada yang sebelumnya"

(Partisipan 4)

Selain mempercepat proses penyembuhan pasien, dampak perilaku caring bagi pasien pasien yang lain adalah pasien menjadi lebih semangat menghadapi penyakitnya. Hal ini sesuai dengan pernyataan dibawah ini:

"Maksudnya mereka jadi semangat sih menghadapi penyakitnya gitu kan. Misalnya ketika pasien menghadapi sakit yang seperti itu dengan adanya support system, dengan adanya perawat yang caring itu dan keluarga yang mendampinginya dia akan apa ya.. kopingnya jadi adaptif. Justru tidak membuat dia down, dan dia akan terus berjuang melawan sakitnya karna kan dengan penjelasan yang terapeutik juga kan dari perawat itu sangat membantu sih dek"

(Partisipan 10)

4.6. Hambatan Mahasiswa Profesi Ners dalam Menerapkan Perilaku Caring

Berdasarkan hasil analisa data didapatkan 3 hambatan mahasiswa profesi ners dalam menerapkan perilaku caring yaitu perawat melarang, pasien dan keluarga tidak kooperatif dan kurangnya waktu untuk bersama pasien.

Dalam menerapkan perilaku caring ternyata ada beberapa hambatan yang dirasakan partisipan sebagai mahasiswa profesi ners. Hambatan yang dirasakan partisipan antara lain dari perawat itu sendiri. Partisipan menjelaskan ketika mereka akan menerapkan perilaku caring pada pasien terkadang ada beberapa perawat melarang untuk melakukannya. Salah satu contohnya adalah perawat marah ketika mahasiswa profesi ners menanyakan kondisi pasien, padahal itu adalah tugas dari mahasiswa profesi ners. Penjelasan diatas sesuai dengan pernyataan partisipan berikut:
"Ketika kakak bertanya-tanya sama pasien, ada satu perawat yang mengatakan "Ngapain ko tanya-tanya itu dek pasien? Lebih baik ko duduk diam di sini manis!"

(Partisipan 1)

Hambatan dalam menerapkan perilaku caring juga bisa disebabkan dari pasien dan keluarga pasien. Partisipan pada penelitian ini mengatakan bahwa ketika mereka menerapkan perilaku caring pada pasien, beberapa pasien berespon negatif dan juga keluarga pasien terkadang tidak percaya dengan partisipan ketika menerapkan perilaku caring pada pasien. Hal ini sesuai dengan pernyataan partisipan dibawah ini:

"Kadang respon yang kita berikan, kita lakukan untuk dia, tapi terkadang mereka menganggap negatif. Ada beberapa kita memberikan injeksi, dia mengatakan, kita akan menyuntik mati seperti itu"

(Partisipan 8)

"Tapi kita tetap berusaha "aduh pak, emang yang seperti itu loh pak yang kami pelajari", bahkan udah kami buat kayak gitu "Enggak, kamu kan masih mahasiswa, kamu masih praktek disini, kamu belum tau apa-apa, kau belum ada makan asam garam kehidupan, aku lebih tau lagi, jangan pande-pandean lah!”, dibilangnya kayak gitu. Tapi kan kita tetap sabar, terus besoknya kita tetap komunikasi"

(Partisipan 9)

Partisipan dalam penelitian ini menjelaskan bahwa mereka memiliki hambatan dalam menerapkan perilaku caring kepada pasien. Salah satu hambatannya adalah banyak tugas non keperawatan (tugas luar) yang dibebankan kepada mahasiswa profesi ners. Pihak rumah sakit dimana partisipan menjalankan tahap profesi sering membebankan tugas luar kepada partisipan sebagai mahasiswa profesi ners, padahal tugas luar tersebut tidak sesuai di ranah partisipan sebagai mahasiswa profesi ners. Hal ini sesuai dengan pernyataan dibawah ini:

"Contohnya banyak pekerjaan yang harus kita lakukan. Kayak kakak bilang tadi lah, beban kerjanya tinggi sementara disini kan kondisinya perawat tidak hanya mengerjakan pekerjaannnya 
perawat, tapi pekerjaan non keperawatan

pun juga dikerjakan, contohnya mengurus jaminan, mengantar pasien foto ke radiologi, mengantar pasien scanning, mengantar apa kultur pasien gitu kan harus ke atas, padahal itu kan bukan pekerjaan perawat, jadi itu menurut kakak juga salah satu hambatan"

(Partisipan 3)

\section{PEMBAHASAN}

Kepedulian merupakan salah satu bentuk dari perilaku caring yang dapat diberikan kepada pasien maupun keluarga pasien dalam praktik pelayanan keperawatan. Dari hasil penelitian, diperoleh menciptakan rasa peduli yang tinggi menurut mahasiswa profesi ners adalah dengan peduli pada pasien. Hal ini sesuai dengan pendapat Watson (2007) yang mendefinisikan caring adalah suatu tindakan keperawatan yang dilakukan setiap hari secara terus menerus, tulus, ikhlas, peduli dengan masalah yang dihadapi pasien

Perilaku caring juga ditunjukkan dengan kemampuan komunikasi terapeutik yang ditetapkan perawat. Dari hasil penelitian, beberapa partisipan menjelaskan bahwa mereka berusaha untuk berkomunikasi secara terapeutik. Karaoz (2005) dalam penelitiannya juga menjelaskan bahwa komunikasi merupakan elemen yang penting dalam hubungan perawat dan pasien. Komunikasi dipandang Karaoz sebagai alat penting untuk mendukung emosional pasien dan mendorong pasien untuk ikut terlibat dalam perawatan mereka. Partisipan pada penelitian Karaoz juga mengatakan bahwa hubungan dan perawatan yang baik bergantung pada komunikasi yang baik ${ }^{[10]}$. Hal yang sama juga dikatakan Begum \& Slavin (2012) dimana salah satu persepsi mahasiswa keperawatan dalam penelitiannya mengatakan bahwa caring sebagai komunikasi.

Hubungan saling percaya antara perawat dan pasien merupakan hal yang penting dalam pemberian asuhan keperawatan. Hubungan ini akan meningkatkan penerimaan terhadap perasaan positif dan negatif antara perawat dan pasien Perilaku caring perawat yang mencerminkan faktor ini dalam memberikan asuhan keperawatan adalah mengucapkan salam ketika berinteraksi dengan pasien, memperkenalkan diri pada awal pertemuan dengan pasien, berbicara dengan suara yang lembut, menjelaskan prosedur tindakan setiap akan melakukan tindakan ${ }^{[4]}$. Hal ini sesuai dengan hasil penelitian bahwasanya partisipan membina hubungan saling percaya kepada pasien saat pertama kali bertemu dengan pasien dan memperkenalkan diri kepada pasien.

Pendidikan kesehatan biasa dilakukan saat partisipan berkomunikasi dengan pasien maupun keluarga pasien. Hal ini juga sesuai pernyataan partisipan pada penelitian ini dimana partisipan juga memberikan pendidikan kesehatan kepada pasien maupun keluarga pasien. Setiawan, Hatthakit, Boonyoung dan Engebretson (2010) dalam penelitiannya juga menjelaskan perawat yang sudah diberikan pengetahuan tentang caring sudah mulai terbiasa untuk memberikan pendidikan kesehatan pada pasien dan keluarga.

Seorang mahasiswa profesi ners sudah seharusnya bertindak sesuai evidence based practice and research yaitu bekerja secara profesional dalam setiap tindakan asuhan keperawatan secara holistik. Berdasarkan hasil penelitian, didapatkan beberapa partisipan mengatakan berusaha untuk bertindak secara holistik ketika merawat pasien. Tindakan holistik yang dimaksudkan partisipan dalam penelitian ini adalah mereka tidak hanya melakukan tindakan keperawatan saja kepada pasien melainkan juga memberikan pengetahuan yang sudah mereka dapatkan di tahap akademik kepada pasien dan juga keluarga pasien. Hal ini sesuai dengan hasil penelitian Green (2004) mengenai perilaku caring perawat yang mendapatkan hasil bahwa menurut perawat, perawat yang memiliki perilaku caring adalah (1) perawat yang menghargai kliennya sebagai manusia, (2) perawat yang selalu hadir untuk klien, dan (3) perawat yang profesional, bekerja dengan pengetahuan dan terampil dalam tindakan.

Perawat harus menyadari bahwa lingkungan internal dan eksternal berpengaruh terhadap kesehatan dan kondisi penyakit pasien. Pada penelitian ini, beberapa partisipan mengatakan salah satu perilaku caring yang sudah mereka terapkan kepada pasien diantaranya dengan mengobservasi atau memonitor keadaan pasien. Penelitian yang dilakukan Yuliawati (2012) juga menjelaskan bahwa sebagian besar pasien mempersepsikan aspek utama dari caring perawat adalah memonitor kondisi pasien secara terus-menerus serta kompetensi klinis yang ditunjukkan oleh perawat.

Mendahulukan kepentingan pasien juga sesuai dengan penelitian Karaoz (2005) dimana salah satu hubungan profesional dan saling 
membantu antara perawat dan pasien yang ditunjukkan dalam sikap concern yaitu dengan memprioritaskan kebutuhan pasien dalam proses perawat.

Nurbiyati (2013) menjelaskan salah satu sikap caring perawat adalah dengan menganggap pasien itu seperti keluarga sendiri. Pernyataan tentang mengkeluargakan yang juga diungkapkan oleh partisipan pada penelitian ini akan berdampak positif bagi perawat dan juga pasien itu sendiri. Bila sudah tercipta suasana yang berkekeluargaan maka perawat dalam melakukan tindakan keperawatan tidak akan canggung dan pasien akan lebih kooperatif kepada perawat dalam segala hal, khususnya keperawatan ${ }^{[14]}$.

Bersikap menghormati pasien pada penelitian ini juga dicontohkan dengan menghargai pasien. Pada penelitian ini contoh menghargai pasien yang dikemukakan partisipan adalah dengan tetap melakukan komunikasi pada pasien walaupun pasien dalam kondisi tidak sadar. Karaoz (2005) pada penelitiannya juga menjelaskan bahwa salah satu hubungan profesional dan saling membantu antara perawat dan pasien dicontohkannya dengan menghormati pasien. Pasien tidak boleh dipandang sebagai objek atau badan saja. Sebaliknya, mereka dipandang sebagai keseluruhan dan bertindak dengan hormat.

Seorang perawat ketika memberikan pelayanan kepada pasiennya disamping melalui diagnosa obat yang disarankan oleh dokter, perawat juga melakukan pendekatan-pendekatan yang mendukung proses kesembuhan penyakit pasien secara pribadi dengan melakukan komunikasi secara pribadi baik secara verbal maupun non verbal. Tersenyum merupakan salah satu indikator penting seorang perawat bersikap ramah, hangat, bergembira dan sabar terhadap pasien dan keluarga. Hal ini sesuai hasil penelitian yang diperoleh bahwa partisipan berperilaku sopan kepada pasien dan keluarga pasien yang meliputi ramah pada pasien, tersenyum ketika melihat pasien dan menyentuh pasien saat berkomunikasi dengan pasien.

Perilaku caring perawat telah terbukti memberikan dampak yang sangat besar bagi pasien maupun perawat. Dampak perilaku caring yang dikemukakan partisipan yang lain adalah dengan partisipan berperilaku caring pada pasien, dapat merubah persepsi keluarga pasien pada perawat. Banyak pasien dan keluarga pasien mengatakan perawat sekarang ramah-ramah. Hal ini sesuai dengan hasil penelitian Gaghiwu, Ismanto dan Babakal (2013) menunjukkan bahwa sebagian besar pasien menyatakan perilaku caring perawat sudah baik, pasien berpendapat bahwa perawat sekarang lebih ramah dan bersedia menjelaskan dengan sabar ketika keluarga pasien bertanya tentang kondisi pasien, berbeda dengan perawat zaman dahulu.

Hasil penelitian juga menjelaskan bahwa dengan adanya perilaku caring, pasien menjadi lebih percaya dengan mahasiswa profesi ners. Hal ini sejalan dengan penelitian Setiawan, Hatthakit, Boonyoung dan Engebretson (2010) dimana didapatkan hasil bahwa manfaat perilaku caring pada perawat salah satunya adalah dapat menjalin hubungan yang lebih dekat dengan pasien dan meningkatkan kepercayaan yang lebih besar kepada pasien dan keluarga.

Dampak perilaku caring bagi pasien yang lain adalah pasien merasa nyaman dengan mahasiswa profesi ners. Pada studi kualitatif oleh Finch pada tahun 2008 mengenai dampak perilaku caring juga didapatkan hasil bahwa terjadi peningkatan kesehatan pasien ke arah yang lebih baik, peningkatan fisik dan emosional. Secara fisik klien menjadi lebih nyaman, memiliki pengetahuan yang lebih mengenai status kesehatan mereka, lebih tenang, santai, dan peningkatan pandangan hidup.

Melakukan perilaku caring tidak selalu menghasilkan hasil yang positif. Partisipan dalam penelitian ini kadang menerima berbagai bentuk umpan balik negatif seperti komentar yang menjengkelkan atau tidak menyenangkan. Partisipan pada penelitian ini mengatakan ketika mereka berperilaku caring kepada pasien terkadang pasien dan keluarga berespon negatif kepada mereka. Tidak hanya pasien dan keluarganya, ketika melakukan perilaku caring mahasiswa juga mendapatkan respon negatif dari perawat di rumah sakit. Hal ini sejalan dengan penelitian Setiawan, Hatthakit, Boonyoung dan Engebretson (2010) yang didapatkan hasil bahwa terkadang partisipan pada penelitiannya menerima umpan balik negatif dari rekan-rekan perawat lainnya ketika melaksanakan protokol caring.

Tingginya beban kerja yang dilakukan oleh perawat menyebabkan tingginya stres yang terjadi pada perawat sehingga menurunkan motivasi perawat untuk melakukan caring. Sobirin (2006) dalam penelitiannya juga mendapatkan hubungan yang signifikan antara beban kerja perawat dengan pelaksanaan perilaku caring perawat. Beban kerja yang tinggi 
menyebabkan kelelahan pada perawat sehingga dapat menurunkan motivasi perawat untuk bersikap caring $^{[17]}$. Hal ini sesuai dengan hasil penelitian dimana partisipan mengeluhkan kurangnya waktu untuk bersama pasien dikarenakan banyaknya tugas luar yang dibebankan kepada mahasiswa profesi ners sehingga menghambat mereka untuk menerapkan perilaku caring kepada pasien.

\section{KESIMPULAN}

Berdasarkan hasil wawancara mendalam yang dilakukan terhadap sepuluh partisipan, maka penelitian ini menemukan ada 4 tema terkait dengan pengalaman mahasiswa profesi ners Fakultas Keperawatan Universitas Sumatera Utara dalam menerapkan perilaku caring pada pasien di Rumah Sakit Pendidikan Kota Medan, yaitu (1) memperlihatkan rasa peduli yang tinggi dalam menerapkan caring, (2) menjalin komunikasi yang menciptakan trust dengan pasien, (3) melakukan tindakan keperawatan secara holistik kepada pasien, (4) menunjukkan sikap menghormati pasien. Selain pengalaman tersebut, penelitian ini juga mengungkapkan dampak perilaku caring dan hambatan yang dialami mahasiswa profesi ners dalam menerapkan perilaku caring. Mengingat pentingnya penerapan perilaku caring tersebut, maka direkomendasikan kepada mahasiswa pendidikan tahap profesi ners untuk terus meningkatkan perilaku caring kepada pasien. Selanjutnya, bagi institusi pendidikan keperawatan ataupun rumah sakit dapat membuat standar perilaku caring sehingga dapat meningkatkan kualitas pelayanan kepada pasien.

\section{DAFTAR PUSTAKA}

Begum, S., \& Slavin, H. 2012. Perceptions of "Caring" in Nursing Education by Pakistani Nursing Students: An exploratory study. Nurse Education Today, 32(3), 332-336. doi:10.1016/j.nedt.2011.10.011.

Dedi, B., Setyowati, \& Afiyanti, Y. 2008. Perilaku Caring Perawat Pelaksana di Sebuah Rumah sakit di Bandung: Studi Grounded Theory. Jurnal Keperawatan Indonesia, 12(1): 40-46

Gaghiwu, L., Ismanto, A.Y., \& Babakal, A. 2013. Hubungan Perilaku Caring Perawat dengan Stres Hospitalisasi pada Anak Usia Toddler di Irina E BLU RSUP Prof. Dr . R. Kandou Manado. ejournal Keperawatan (e-Kp). 1(1): 1-7
Glembocki, M.M., \& Dunn, K.S. 2010. Building an Organizational Culture of Caring: Caring Perceptions Enhanced With Education. The Journal of Continuing Education in Nursing. 41(12): 565-570.

Green, A. 2004. Caring Behavior as Perceived of Nurse Practitioners. Journal of the American Academy of Nurse Practitioners. 16: 283-290

Karaoz, S. 2005. Turkish Nursing Students' Perception of Caring. Nurse Education Today. 25: 31-40

Nurbiyati, T. 2013. Persepsi Pasien Tentang Perilaku Caring Perawat dalam Pelayanan Keperawatan. Prosiding Konferensi Nasional PPNI Jawa Tengah 2013: 256261

Nurhidayah, R.E. 2011. Pendidikan Keperawatan. Medan: USU Press

Prompahakul, C., Nilmanat, K., \& Kongsuwan, W. 2011. Nurses' Caring Behavior for Dying Patient in Southern Thailand. Nurse Media Journal of Nursing. 1(2): 147-158

Potter, P.A., \& Perry, A.G. 2005. Fundamental of Nursing : Concepts, Process \& Practice. $6^{\text {th }}$ ed. St Louis, MI: Elsevier Mosby

Schaefer, K.M. 2003. Caring Behaviors of Advanced Practice Nursing Students. Journal of Holistic Nursing. 21(1): 36-51

Setiawan., Hatthakit, U., Boonyoung, N., \& Engebretson, J.C. 2010. Creating a Caring Atmosphere in an Intensive Stroke Care Unit in Indonesia: An Action Research Approach. Malaysian of Nursing Journal: 1-10

Sobirin, C. 2006. Hubungan Beban Kerja dan Motivasi dengan Penerapan Perilaku Caring Perawat Pelaksana di Ruang Rawat Inap RS Islam Samarinda. Jakarta: UI Press

Tomey, A.M., \& Alligood, M.R. 2006. Nursing Theorist and Their Work. $6^{\text {th }}$ ed. Philadelphia: Mosby Year - Book Inc

Watson, J. 2007. Watson's Theory of Human Caring and Subjective Living Experiences: Carative Factors/Caritas Processes As A Disciplinary Guide To The Professional Nursing Practice. Texto Contexto Enferm, Florianopolis. 16(1): 129-135

Wolf, Z.R., Miller, P.A., \& Devine, M. 2003. Relationship Between Nurse Caring and Patient Satisfaction in Patients 
Undergoing Invasive Cardiac Procedures. Medical Surgical Nursing. 12(6): 391-396 Yuliawati, A.D. 2012. Gambaran Perilaku Caring Perawat terhadap Pasien di Ruang Rawat Inap Umum RS. Dr. H. Marzoeki Mahdi Bogor. Jakarta: UI Press 